\title{
RAIINSTEK
}

Jurnal Terapan Sains \& Teknologi

E-ISSN: 2721-6209

Fakultas Sains dan Teknologi - Universitas Kanjuruhan Malang

Vol. 2, No. 2, 2020

\section{PENERAPAN SIMPLE ADDITIVE WEIGHTING PADA PEMILIHAN CALON PESERTA OSN DI SMPN 1 AMPELGADING}

\author{
Huzairi $^{1}$, Hari Lugis Purwanto ${ }^{2}$ \\ Sistem Informasi, Universitas Kanjuruhan Malang ${ }^{1,2}$ \\ Email huzairi101090@gmail.com, hari_lugis@unikama.ac.id
}

\begin{abstract}
Abstrak. Proses seleksi penentuan calon peserta olimpiade sains nasional di SMPN 1 Ampelgading dengan rata-rata nilai masih kurang tepat, karena pada proses seleksi dengan rata-rata nilai tertinggi tidak ada nilai yang di prioritaskan sebagai nilai penentu. Seharusnya dari beberapa nilai yang dijadikan kriteria penilaian terdapat perberdaan bobot kriteria. Berdasarkan permasalahan tersebut maka perlu dirancang sebuah sistem yang melibatkan suatu metode sehingga menghasilkan sebuah keputusan yang sesuai untuk penyeleksian data. Pada penelitian ini digunakan metode SAW (Simple Additive Weighting) dalam pengambilan keputusan. Metode SAW merupakan metode dengan penjumlahan terbobot. Metode ini dipilih karena mampu menyeleksi alternatif terbaik dari sejumlah alternatif berdasarkan kriteria pembobotan yang telah ditentukan. Setelah dilakukan pengujian dan analisis dengan perhitungan secara manual dapat diketahui bahwa hasil dari perhitungan sistem sama dengan perhitungan manual, sehingga sistem ini dapat digunakan untuk pemilihan calon peserta olimpiade sains di SMPN 1 Ampelgading.
\end{abstract}

Kata Kunci : Sistem Pendukung Keputusan, Metode SAW, OSN.

\section{PENDAHULUAN}

Berdasarkan hasil wawancara dengan ketua panitia seleksi calon peserta olimpiade sains nasional yaitu Bpk. Zamroni Ato'ilah, S.Pd. menyatakan bahwa proses seleksi dengan rata-rata nilai masih kurang tepat, karena pada proses seleksi dengan rata-rata nilai tertinggi tidak ada nilai yang di prioritaskan sebagai nilai penentu. Seharusnya dari beberapa nilai yang dijadikan kriteria penilaian terdapat perberdaan bobot kriteria, Berdasarkan uraian permasalahan tersebut, maka perlu dirancang sebuah aplikasi untuk membantu proses seleksi calon peserta olimpiade sains nasional tingkat kabupaten di SMP Negeri 1 Ampelgading. Pada penelitian ini, peneliti menggunakan metode SAW (Simple Additive Weighting) dalam pemilihan calon peserta Olimpiade Sains Nasional (OSN).

Dari beberapa penelitian yang menjelaskan tentang kelebihan metode SAW (Simple Additive Weighting) yaitu menurut, Utomo (2016) dalam penelitiannya yang berjudul Penerapan Metode SAW (Simple Additive Weighting) pada Sistem Pendukung Keputusan Untuk Pemberian Beasiswa pada SMA Negeri 1 Cepu Jawa Tengah menjelaskan bahwa: Kelebihan metode SAW terletak pada kemampuannya untuk melakukan penilaian secara lebih tepat karena didasarkan pada nilai kriteria dan bobot preferensi yang sudah ditentukan, selain itu SAW juga dapat menyeleksi alternatif terbaik dari sejumlah alternatif yang ada karena adanya proses perangkingan setelah menentukan bobot untuk setiap atribut.

Darmastuti (2013) dalam penelitiannya yang berjudul Implementasi Metode Simple Additive Weighting (SAW) dalam Sistem Informasi Lowongan Kerja Berbasis Web untuk Rekomendasi Pencari Kerja Terbaik menjelaskan bahwa: Kelebihan metode SAW yaitu dapat menentukan nilai bobot untuk setiap atribut, kemudian dilanjutkan dengan proses perangkingan yang akan menyeleksi aternatif terbaik dari sejumlah alternatif terbaik. Total perubahan nilai yang dihasilkan oleh metode SAW lebih banyak sehingga metode SAW sangat relevan untuk menyelesaikan masalah pengambilan keputusan. 
Widyaningsih dan Giovanni (2016) dalam penelitiannya yang berjudul Penentuan Peserta Lomba Kompetensi Siswa Menggunakan Simple Additive Weighting (SAW) Studi Kasus SMK Negeri 2 Palangkaraya, menyatakan bahwa: Dengan adanya sistem pendukung keputusan dengan menggunakan metode Simple Additive Weighting (SAW) yang banyak digunakan dalam menghadapi situasi Multiple Attribute Decision Making (MADM) mampu menyeleksi peserta lomba, sehingga dapat memberikan rekomendasi untuk diambil keputusan yang terbaik bagi siswa yang layak mewakili sekolah pada LKS-SMK tingkat provinsi. Hasil keputusan yang dikeluarkan oleh pihak sekolah akan memberikan informasi yang transparan dan diketahui kebenarannya dari perhitungan sistem.

Pasaribu (2017) dalam penelitiannya yang berjudul Implementasi Sistem Pendukung Keputusan Metode Simple Additive Weighting Pemilihan Siswa Olimpiade Sains Tingkat Kota di SMAN 11 Bandung, menyatakan bahwa: Pemberian kriteria-kriteria dalam pemilihan peserta Olimpiade Sains tingkat kota di SMA Negeri 11 Bandung dapat membantu dalam mengambil keputusan untuk menentukan peserta Olimpiade Sains tingkat kota di SMA Negeri 11 Bandung sesuai dengan kompetensinya secara adil (fair). Metode Simple Additive Weighting (SAW) dapat menghasilkan rekomendasi peserta Olimpiade Sains tingkat kota dari SMA Negeri 11 Bandung sesuai dengan kriteria yang ditentukan. Sistem pengambilan keputusan dengan menggunakan metode Simple Additive Weighting (SAW) telah membantu berkurangnya kesalahan dalam menentukan pemilihan peserta Olimpiade Sains tingkat kota dari SMA Negeri 11 Bandung.

Dalam penelitian lain yaitu, Situmorang (2015) yang berjudul Sistem Pendukung Keputusan Pemilihan Calon Peserta Olimpiade Sains Tingkat Kabupaten Langkat pada Madrasah Aliyah Negeri (MAN) 2 Tanjung Pura dengan Menggunakan Metode Simple Additive Weighting (SAW), menyatakan bahwa berdasarkan hasil analisis yang didapatkan, maka dapat diambil beberapa kesimpulan diantaranya sebagai berikut: Peringkat rangking tidak menjadi prioritas dalam pemilihan siswa yang dapat mengikuti olimpiade sains. Sistem pendukung keputusan ini dapat mempermudah sekolah Madrasah Aliyah Negeri 2 Tanjung Pura dalam menentukan peserta olimpiade sains. Dengan menerapkan metode SAW sistem yang dirancang mampu menampilkan hasil keputusan pemilihan calon peserta olimpiade sains berdasarkan kriteria nilai yang diinputkan.

Berdasarkan permasalahan di atas, dibutuhkan sistem pendukung keputusan yang difokuskan pada pemilihan calon peserta yang layak untuk mengikuti Olimpiade Sains Nasional (OSN) oleh panitia seleksi di SMP Negeri 1 Ampelgading dengan menggunakan metode SAW (Simple Additive Weighting).

\section{METODE PENELITIAN}

\section{Model Penelitian Pengembangan}

Model penelitian yang digunakan pada penelitian ini adalah penelitian dan pengembangan (research and development). Sistem pendukung keputusan pemilihan calon peserta Olimpiade Sains Nasional (OSN) menggunakan metode SAW (Simple Additive Weighting) di SMP Negeri 1 Ampelgading, peneliti mengacu pada model pengembangan Waterfall. Berikut adalah gambar model air terjun (waterfall).

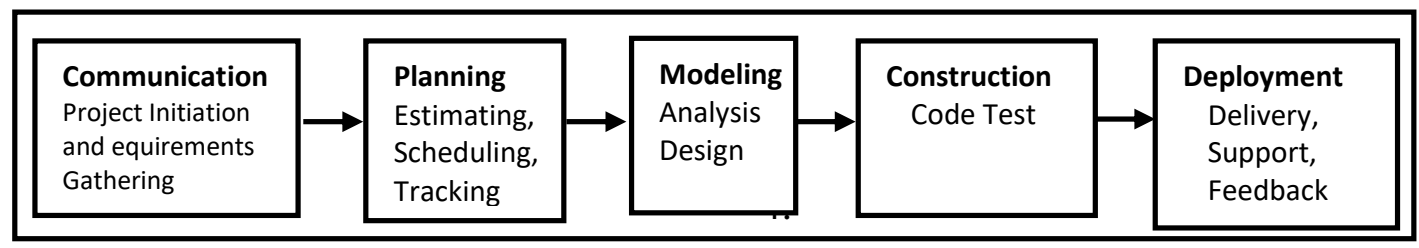

\section{Jenis Data}

Gambar 1. Model Waterfall (Pressman, 2015) 


\section{Jurnal Terapan Sains \& Teknologi}

Fakultas Sains dan Teknologi - Universitas Kanjuruhan Malang

Jenis data yang digunakan dalam penulisan penelitian pengembangan, yaitu prosedur penelitian yang menghasilkan data dalam angka, meliputi informasi tentang hasil penerapan metode SAW (Simple Additive Weighting) pada sistem.

\section{Instrumen Pengumpulan Data}

Instrumen pengumpulan data dengan melakukan observasi dan wawancara dengan ketua panitia seleksi calon peserta osn yang bernama Zamroni Ato'ilah, S.Pd., penulis mendapatkan informasi dan data terkait dengan permasalahan yang ada pada proses seleksi calon peserta osn.

\section{Teknik Analisis Data}

Teknik analisis dalam penelitian ini adalah dengan melakukan uji coba produk yang diteliti dengan beberapa pengguna, merekap hasil uji coba yang dilakukan serta menampilkan hasil rekap uji coba yang dilakukan dalam bentuk angka atau table.

\section{Simple Additive Weighting (SAW)}

Nofriansyah (2014:11), dalam bukunya yang berjudul Konsep Data Mining Sistem Pendukung Keputusan, menjelaskan metode Simple Additive Weighting sering juga dikenal dengan istilah metode penjumlahan terbobot. Konsep dasar metode Simple Additive Weighting adalah mencari penjumlahan terbobot dari rating kinerja pada setiap alternatif pada setiap atribut. Metode Simple Additive Weighting disarankan untuk menyelesaikan masalah penyeleksian dalam sistem pengambilan keputusan multi proses. Metode Simple Additive Weighting merupakan metode yang banyak digunakan dalam pengambilan keputusan yang memiliki banyak atribut. Metode simple additive weighting membutuhkan proses normalisasi matriks keputusan (x) ke suatu skala yang didapat diperbandingkan dengan semua rating alternatif yang ada. Formula untuk melakukan normalisasi tersebut adalah:

$$
r_{i j}= \begin{cases}\frac{\mathrm{x}_{\mathrm{ij}}}{\operatorname{Max}_{\mathrm{i}} \mathrm{X}_{\mathrm{ij}}} & \text { Jika } \mathrm{j} \text { adalah atribut keuntungan (benefit) } \\ \frac{\operatorname{Min}_{\mathrm{i}} \mathrm{x}_{\mathrm{ij}}}{\mathrm{X}_{\mathrm{ij}}} & \text { Jika } \mathrm{j} \text { adalah atribut biaya (cost) }\end{cases}
$$

Dimana dengan $r_{i j}$ adalah rating kinerja ternormalisasi dari alternatif $\mathrm{A}_{i}$ pada atribut $\mathrm{Cj}: \mathrm{I}=$ $1,2 \ldots, \mathrm{m}$ dan $\mathrm{j}=1,2 \ldots, \mathrm{n}$.

Keterangan

Max Xij = Nilai terbesar dari setiap kriteria $\mathrm{i}$.

Min $\mathrm{Xij}=$ Nilai terkecil dari setiap kriteria $\mathrm{i}$.

$\mathrm{Xij} \quad=$ Nilai atribut yang dimiliki dari setiap kriteria.

Benefit = Jika nilai terbesar adalah terbaik.

Cost $\quad=$ Jika nilai terkecil terbaik.

Nilai Preferensi untuk setiap alternative (Vi) diberikan rumus sebagai berikut:

$V_{i}=\sum_{j=1}^{n} W_{j} r_{i j}$

Keterangan:

$\mathrm{Vi} \quad=$ Rangking untuk setiap alternative.

$\mathrm{Wj} \quad=$ Nilai bobot dari setiap kriteria.

rij $\quad=$ Normalisasi matriks.

$\mathrm{i} \quad=$ Alternatif.

$\mathrm{j} \quad=$ Kriteria.

$\mathrm{n} \quad=$ Banyaknya kriteria

Nilai Vi yang lebih besar mengindikasikan bahwa alternatif Ai lebih terpilih.

\section{HASIL DAN PEMBAHASAN}


1. Model Waterfall

a) Communication

Pada tahap analisis kebutuhan, peneliti melakukan dua tahap yaitu observasi dan wawancara untuk mengetahui permasalahan yang terjadi pada proses seleksi yang dilakukan oleh panitia seleksi calon peserta osn di SMPN 1 Ampelgading, khususnya dalam melakukan perhitungan nilai calon peserta.

\section{b) Planning}

Pada tahap ini dilakukan perencanaan tentang sistem yang akan dibangun dengan melakukan penjadwalan proses pembuatan sistem. Pada tahap ini dilakukan dengan beberapa tahap yang meliputi analisa kebutuhan, mendesain produk, penmrograman, pengujian, dan Implementasi system. Dengan proses tersebut diharapkan program dapat diselesaikan sesuai waktu yang telah ditentukan.

\section{c) Modeling}

Pada tahap modelling dilakukan perencanaan tentang semua kebutuhan fungsional dan nonfungsional. Pada tahap ini aktor yang terlibat pada sistem ditentukan yang selanjutnya menentukan hak akses pada sistem sesuai dengan fungsi pengguna. Hak akses yang telah diterapkan pada sistem antara lain Administrator, Kepala Sekolah, Panitia, dan Peserta. Desain tampilan ini menggunakan UML yang bertujuan untuk mempermudah proses dan alur pengembangan sistem. Berikut adalah gambar rancangan sistem pendukung keputusan pemilihan calon peserta osn di SMPN 1 Ampelgading.

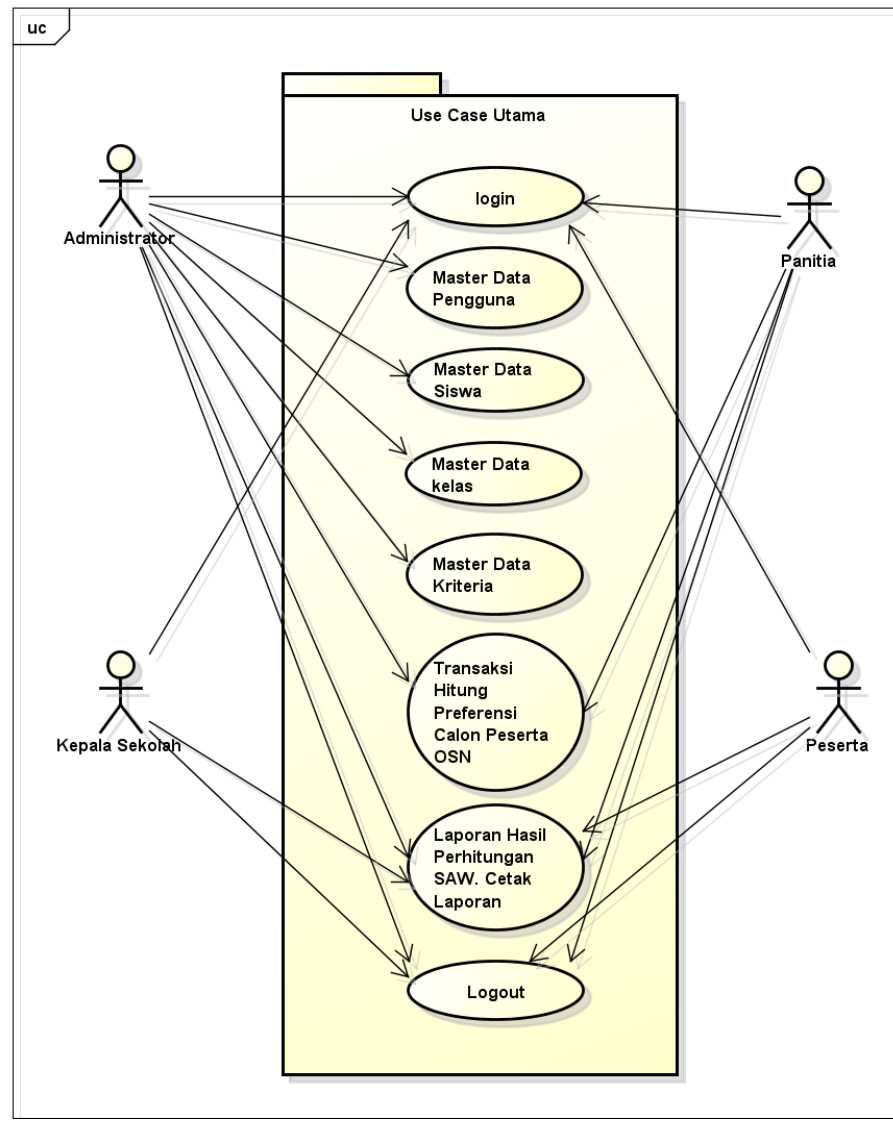

Gambar 2 . Use Case Utama

Class diagram adalah diagram yang menghubungkan antar class yang telah dirancang. Berikut class diagram yang akan dijelas kan pada gambar 3. 


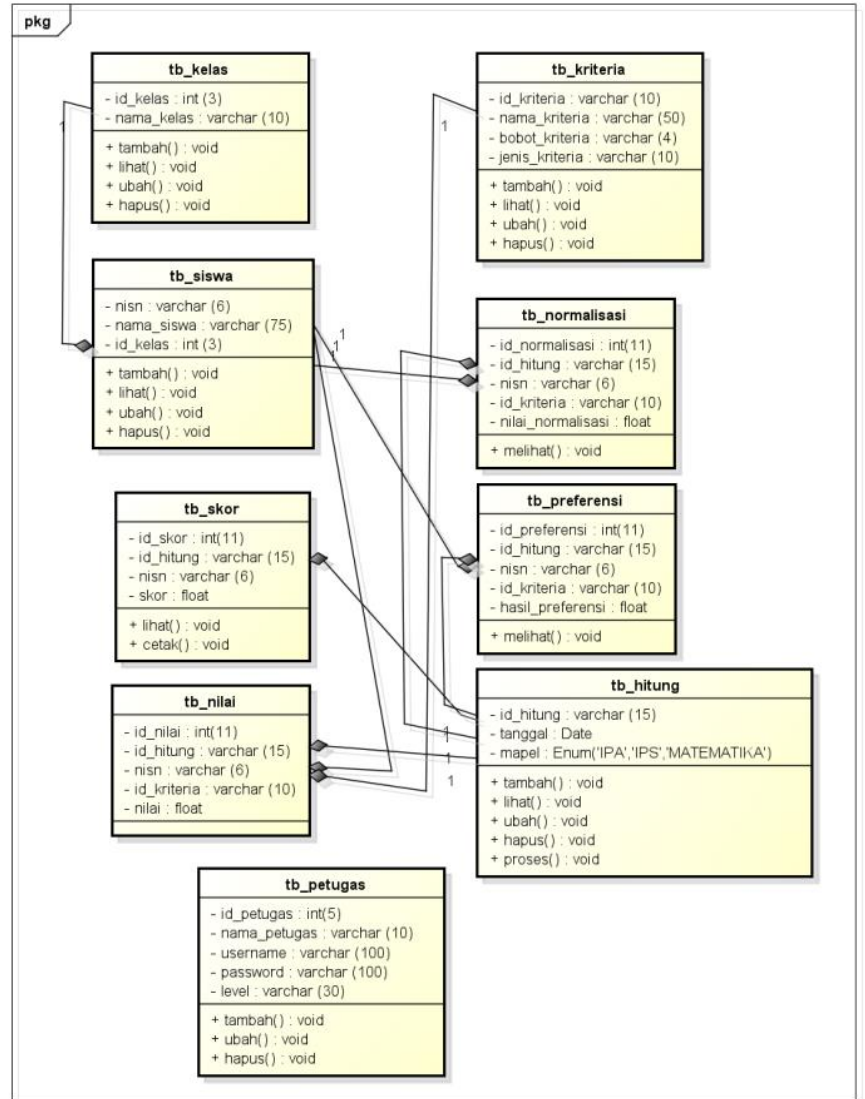

Gambar 3. Class Diagram

\section{d) Construction}

Penerapan metode SAW (Simple Additive Weighting) kedalam sistem berdasarkan data yang telah dibut dan mentranslasikan desain produk yang telah dirancang pada tahap Modelling menjadi sebuah program

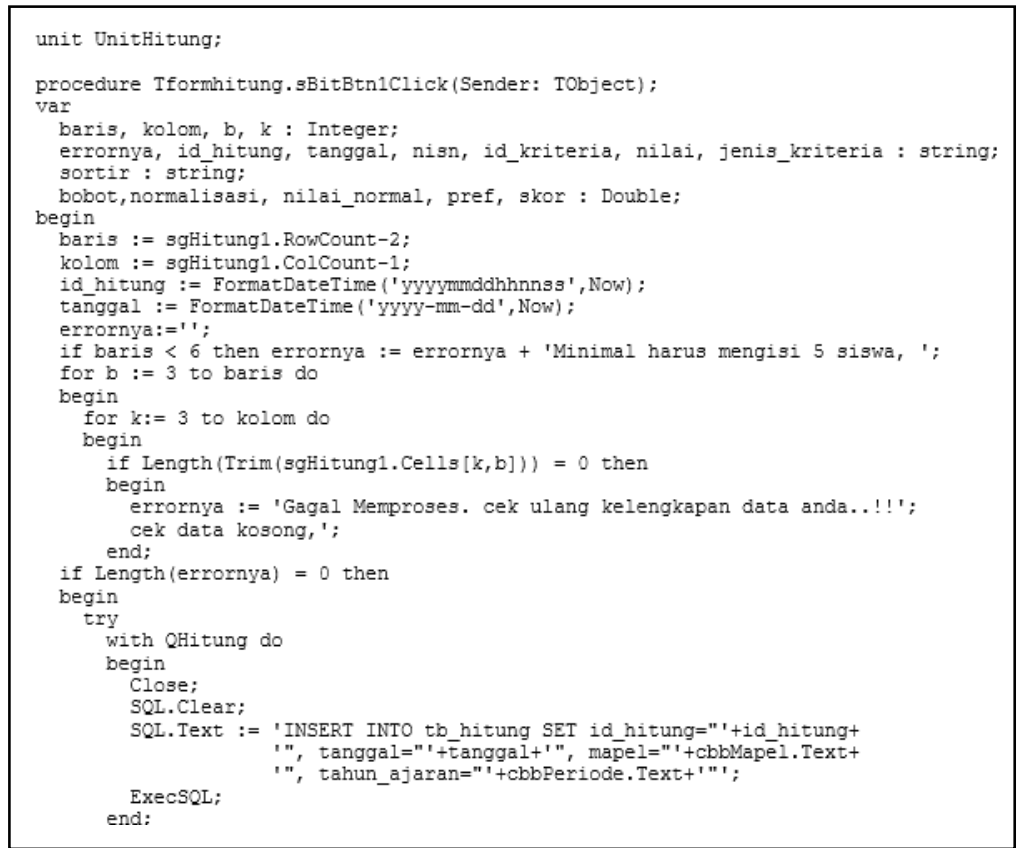


for $b:=3$ to baris do

begin

isn := sgHitung 1 .Cells $[1, b]$;

for $k:=3$ to kolom do

id_kriteria := sgHitung1.Cells $[k, 0]$;

nilai := sgHitungl.Cells $[k, b]$

with QHitung do

egin

SOL. Clear:

SOL. Text := 'INSERT INTO tb nilai SET id hitung="'+id hitung+ '", nisn="'+nisn+'", id_kriteria="'+id_kriteriat

ExecSQL;

for $k:=3$ to kolom do

begin

id kriteria : = sgHitung 1. Cells $[k, 0]$

with QHitung do

begin

Close;

SQL.Text :='SELECT jenis_kriteria FROM tb kriteria WHERE

id_kriteria="'+trim(id_kriteria)+'"'";

Open;

end;

Jenis_kriteria := QHitung.Fields[0].AsString;

if UpperCase (jenis kriteria) = 'BENEFIT' then sortir := 'DESC'

else sortir := 'ASC';

with QHitung do

begin

Close;

SQL.Clear;

SQL.Text := 'SELECT nilai FROM tb_nilai WHERE id_hitung="'+id_hitung+ '" AND id_kriteria=" $"$ +id_kriteriat" " ORDER BY nilai Open; '+sortirt' LIMIT 1', end;

normalisasi := StrToFloat (QHitung.Fields [0].AsString)

for $b:=3$ to baris do

nisn := sgHitung 1 .Cells $[1, \mathrm{~b}]$

nilai_normal := StrToFloat (sgHitung1.Cells $[\mathrm{k}, \mathrm{b}]$ ) / normalisasi with QHitung do

begin

Close;

SQL.Text := 'INSERT INTO tb_normalisasi SET id_hitung="'+id_hitungt '", nisn="'+nisn+'", id_kriteria="' +1 id_kriteria

nilai_normalisasi="' +stringreplace (FloatToStr (nilai_normal) , ' ' ', ' . ', [rfReplaceAll, rfIgnöreCase] I+'"';

end:

end;

for $b$

ttung1.Cells $[1, \mathrm{~b}]$

bobot := StrloFloat (sgHitung1.Cells $[k, 1]$ );

begin

SQL. Text : = 'SELECT nilai normalisasi FROM tb normalisasi WHERE id_hitung="'+id_hitung+

'" AND id_kriteria="'+id_kriteriat'" AND nisn="'+nisn+'"

ORDER BY id_hitung DESC LIMIT 1';

$$
\begin{aligned}
& \text { Open; } \\
& \text { end; }
\end{aligned}
$$

normalisasi := StrToFloat (QHitung. Fields[0].AsString)

begin

Close;

SQL.Text : = 'INSERT INTO tb_preferensi SET id_hitung="'+id_hitung+ '", nisn="'+nisn+'", id_kriteria="' '+id_kriteriāt

hasil_preferensi=" '+stringreplace (FloatToStr (pref) , ' , ', ' . ', [rfReplaceAll, rf IgnoreC ase])+'"';

$$
\begin{aligned}
& \text { ExecSQL: } \\
& \text { end: }
\end{aligned}
$$

for $b:=3$ to baris do

nisn $:=$ sgHitung 1. Cells $[1, b]$

for $k:=3$ to kolom do

id kriteria := sgHitung1.Cells $[\mathrm{k}, 0]$;

begin

Close;

SQL.Text := 'SELECT hasil preferensi FROM tb preferensi WHER id_hitung="'+id_hitung+

ORDER BY id hitung DESC '" AND id_kriteria="'+id_kriteriat'" AND nisn="'+nisn+'" Open;

pref := StrToFloat (0Hitung Fielde [0] hastring) ;

skor := skor+pref;

endi

with QHitung do

begin

Close;

SQL.Clear;
SQL.Text := 'INSERT INTO tb_skor SET id_hitung="'+id_hitung+ 


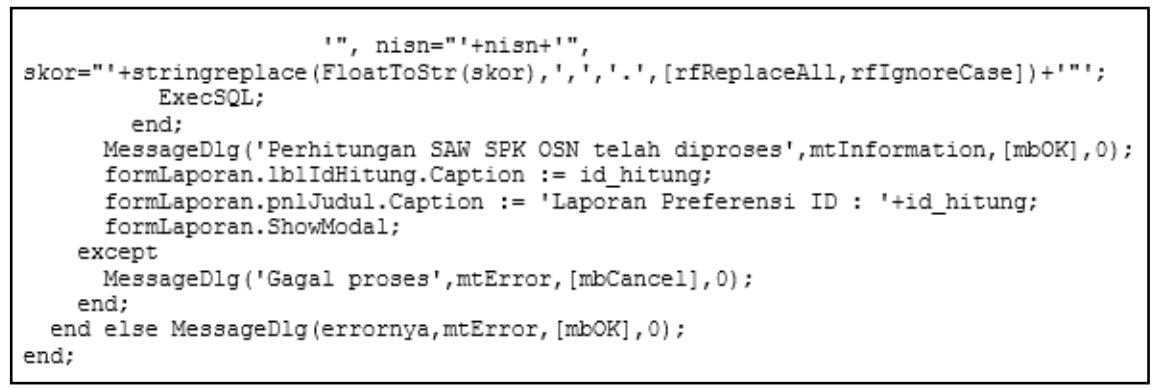

Lanjutan Gambar 4. Source Code Metode SAW Pada Sistem

Setelah tahap pembuatan produk telah selesai maka akan dilanjutkan dengan uji coba produk. Uji coba produk ini bertujuan untuk mengetahui kemungkinan terjadinya kesalahan dengan cara menganalisa proses sistem sesuai dengan peosedur yang telah ditentukan. Serta untuk mengetahui produk yang dibuat sudah sesuai dengan yang diinginkan atau belum. Jika masih belum sesuai maka akan dilanjutkan tahap revisi produk atau perbaikan produk.

Tabel 1. Pengujian Blackbox

\begin{tabular}{|c|c|c|c|c|}
\hline \multicolumn{2}{|c|}{ Tujuan Tes } & \multicolumn{3}{|l|}{ Melakukan Uji Coba } \\
\hline Item Uji & $\begin{array}{l}\text { Tes } \\
\text { ID }\end{array}$ & Hasil yang diharapkan & $\begin{array}{c}\text { Hasil } \\
\text { pengujian }\end{array}$ & $\begin{array}{l}\text { Kesim } \\
\text { pulan }\end{array}$ \\
\hline $\begin{array}{l}\text { Login } \\
\text { Sistem }\end{array}$ & UJ-01 & $\begin{array}{l}\text { Login sistem berjalan dengan baik sesuai hak } \\
\text { akses yang terdaftar pada sistem }\end{array}$ & $\begin{array}{l}\text { Sesuai } \\
\text { yang } \\
\text { diharapkan } \\
\end{array}$ & Valid \\
\hline $\begin{array}{l}\text { Halaman } \\
\text { utama }\end{array}$ & $\mathrm{UJ}-02$ & $\begin{array}{l}\text { Halaman utama tampil dengan baik dan } \\
\text { tombol-tombol berfungsi dengan baik }\end{array}$ & $\begin{array}{l}\text { Sesuai } \\
\text { yang } \\
\text { diharapkan }\end{array}$ & Valid \\
\hline $\begin{array}{l}\text { Mastering } \\
\text { data siswa }\end{array}$ & UJ-03 & $\begin{array}{l}\text { Halaman master data siswa terdapat beberapa } \\
\text { fungsi yaitu tambah data siswa, import data } \\
\text { siswa, hapus data siswa, ubah data siswa, cari } \\
\text { data siswa, combobox filter kelas dan tombol } \\
\text { simpan semua bekerja dengan baik }\end{array}$ & $\begin{array}{l}\text { Sesuai } \\
\text { yang } \\
\text { diharapkan }\end{array}$ & Valid \\
\hline $\begin{array}{l}\text { Mastering } \\
\text { data kelas }\end{array}$ & UJ-04 & $\begin{array}{l}\text { Halaman master data kelas terdapat beberapa } \\
\text { fungsi yaitu tambah kelas, ubah kelas, hapus } \\
\text { kelas, cari kelas semua bekerja dengan baik }\end{array}$ & $\begin{array}{l}\text { Sesuai } \\
\text { yang } \\
\text { diharapkan }\end{array}$ & Valid \\
\hline $\begin{array}{l}\text { Mastering } \\
\text { data } \\
\text { kriteria }\end{array}$ & $\mathrm{UJ}-05$ & $\begin{array}{l}\text { Halaman master data kriteria terdapat } \\
\text { beberapa fungsi yaitu tambah kriteria, ubah } \\
\text { kriteria, hapus kriteria, cari data kriteria semua } \\
\text { bekerja dengan baik }\end{array}$ & $\begin{array}{l}\text { Sesuai } \\
\text { yang } \\
\text { diharapkan }\end{array}$ & Valid \\
\hline $\begin{array}{l}\text { Mastering } \\
\text { pengguna }\end{array}$ & UJ-06 & $\begin{array}{l}\text { Halaman master data pengguna terdapat } \\
\text { beberapa fungsi yaitu tambah pengguna, ubah } \\
\text { pengguna, hapus pengguna, cari data } \\
\text { pengguna semua bekerja dengan baik }\end{array}$ & $\begin{array}{c}\text { Sesuai } \\
\text { yang } \\
\text { diharapkan }\end{array}$ & Valid \\
\hline $\begin{array}{l}\text { Transaksi } \\
\text { hitung } \\
\text { preferensi } \\
\text { calon } \\
\text { peserta } \\
\text { OSN }\end{array}$ & $\begin{array}{l}\text { UJ- } \\
07\end{array}$ & $\begin{array}{l}\text { Halaman transaksi terdapat beberapa } \\
\text { fungsi yaitu combobox pilih mata } \\
\text { pelajaran, combobox tahun pelajaran, } \\
\text { tambah nilai, import nilai, hapus nilai } \\
\text { dan tombol proses hitung, semua fungsi } \\
\text { berjalan dengan baik }\end{array}$ & $\begin{array}{l}\text { Sesuai yang } \\
\text { diharapkan }\end{array}$ & Valid \\
\hline $\begin{array}{l}\text { Laporan } \\
\text { perhitung }\end{array}$ & $\begin{array}{l}\text { UJ- } \\
08 \\
\end{array}$ & $\begin{array}{l}\text { Halaman laporan perhitungan OSN } \\
\text { terdapat beberapa fungsi yaitu melihat }\end{array}$ & $\begin{array}{l}\text { Sesuai yang } \\
\text { diharapkan }\end{array}$ & Valid \\
\hline
\end{tabular}




an OSN hasil laporan nilai siswa sesuai mata
pelajaran dan tahun pelajaran, semua fungsi berjalan dengan baik

Lanjutan Tabel 1. Pengujian Blackbox

\begin{tabular}{|c|c|c|c|c|}
\hline Item Uji & $\begin{array}{l}\text { Tes } \\
\text { ID }\end{array}$ & Hasil yang diharapkan & $\begin{array}{c}\text { Hasil } \\
\text { pengujian }\end{array}$ & $\begin{array}{c}\text { Kesim } \\
\text { pulan }\end{array}$ \\
\hline $\begin{array}{l}\text { Laporan } \\
\text { hasil } \\
\text { seleksi } \\
\text { OSN }\end{array}$ & $\begin{array}{l}\text { UJ- } \\
09\end{array}$ & $\begin{array}{l}\text { Halaman laporan hasil OSN terdapat } \\
\text { beberapa fungsi yaitu melihat hasil } \\
\text { laporan nilai siswa yang lolos seleksi } \\
\text { sesuai mata pelajaran dan tahun } \\
\text { pelajaran, dan tombol cetak. semua } \\
\text { fungsi berjalan dengan baik }\end{array}$ & $\begin{array}{l}\text { Sesuai yang } \\
\text { diharapkan }\end{array}$ & Valid \\
\hline
\end{tabular}

\section{Studi kasus Perhitungan Metode SAW}

Berikut adalah hasil perhitungan nilai siswa peraih 4 besar pada masing-masing kelas 8 dengan total data siswa sebanyak 28 data. Studikasus perhitungan nilai mata pelajaran IPA. Beberapa langkah untuk menyelesaikan perhitungan menggunakan metode SAW.

1. Menentukan jenis-jenis kriteria dan alternatif. Dalam penelitian ini terdapat 28 alternatif.

Tabel 2. Data Alternatif

\begin{tabular}{cl}
\hline ALTERNATIF & \multicolumn{1}{c}{ NAMA ALTERNATIF } \\
\hline A1 & A'as Ariska Safitri \\
\hline A2 & Aisah Putri Ramandani \\
\hline A4 & Dellyziea Tri Mardya \\
\hline A5 & Gladhis Putri Evrillia \\
\hline A6 & Farah Khirziyah Salsabila \\
\hline A7 & Syarla Reffika Putri \\
\hline A8 & Fairynaya Candra \\
\hline A9 & Olivia Laila Ramadhani \\
\hline A10 & Eisyiyah Putri Ilvia \\
\hline A11 & Chusnul Tri Lestari \\
\hline A12 & Lintang Mauliza Selua S. \\
\hline A13 & Dino Arix \\
\hline A14 & Dyah Ayu Pramesti Regita C. \\
\hline A15 & Alhamda Rani Diktia Putri \\
\hline A16 & Ratri Divandari \\
\hline A17 & Ika Febrianti \\
\hline A18 & Nia Reta Adytiyas \\
\hline A19 & Alisya Mia Audini \\
\hline A20 & Meta Afisha Rizza Fauziah \\
\hline A21 & Putri Sofiana \\
\hline A22 & Septia Dwi Kamila \\
\hline A23 & Ristantya Andini \\
\hline A24 & Diva Lintang Aisyah Rani \\
\hline A25 & Singka Mefiya Alfa Reza \\
\hline A26 & Devin Anastasia \\
\hline A27 & Syallom Gading Maharani \\
\hline A28 & Amanda Amelia Putri \\
\hline & \\
\hline
\end{tabular}

Kriteria yang akan dijadikan acuan dalam pengambilan keputusan

Tabel 3. Data Kriteria

\begin{tabular}{cc}
\hline Kriteria $(\mathbf{C j})$ & Nama Kriteria \\
\hline $\mathrm{C} 1$ & Rata-rata Ulangan Harian \\
\hline
\end{tabular}




\begin{tabular}{ll}
\hline C2 & Ulangan Tengah Semester (UTS) \\
\hline C3 & Ulangan Akhir Semester (UAS) \\
\hline C4 & Nilai Tes OSN \\
\hline C5 & Nilai Sikap (kehadiran dan kedisiplinan) \\
\hline
\end{tabular}

2. Nilai Bobot pada masing-masing Kriteria

Tabel 4. Bobot Kepentingan Dari Setiap Kriteria

\begin{tabular}{cc}
\hline Kriteria $(\mathbf{C j})$ & Bobot $(\mathbf{W})$ \\
\hline $\mathrm{C} 1$ & 0,15 \\
\hline $\mathrm{C} 2$ & 0,20 \\
\hline $\mathrm{C} 3$ & 0,20 \\
\hline $\mathrm{C} 4$ & 0,40 \\
\hline $\mathrm{C} 5$ & 0,05 \\
\hline
\end{tabular}

Dalam sistem ini menggunakan atribut sama yaitu atribut keuntungan (benefit). Setelah bobot preferensi ditentukan, dibuat matrik berdasarkan tabel-tabel pembobotan sebelumnya.

Tabel 5. Nilai Kriteria Dari Setiap Alternatif

\begin{tabular}{cccccc}
\hline Alternatif & C1 & C2 & C3 & C4 & C5 \\
\hline A1 & 79 & 80 & 79 & 78 & 90 \\
\hline A2 & 79 & 78 & 79 & 76 & 80 \\
\hline A3 & 79 & 78 & 80 & 70 & 90 \\
\hline A4 & 82 & 80 & 82 & 76 & 85 \\
\hline A5 & 78 & 79 & 80 & 68 & 90 \\
\hline A6 & 78 & 78 & 80 & 70 & 85 \\
\hline A7 & 78 & 79 & 80 & 66 & 90 \\
\hline A8 & 78 & 80 & 81 & 78 & 85 \\
\hline A9 & 89 & 90 & 87 & 82 & 90 \\
\hline A10 & 82 & 84 & 85 & 76 & 90 \\
\hline A11 & 84 & 87 & 85 & 66 & 85 \\
\hline A12 & 84 & 87 & 85 & 72 & 90 \\
\hline A13 & 89 & 90 & 95 & 80 & 90 \\
\hline A14 & 88 & 94 & 95 & 82 & 90 \\
\hline A15 & 90 & 88 & 90 & 80 & 90 \\
\hline A16 & 92 & 90 & 92 & 84 & 90 \\
\hline A17 & 86 & 90 & 87 & 76 & 90 \\
\hline A18 & 83 & 90 & 86 & 70 & 85 \\
\hline A19 & 86 & 90 & 86 & 72 & 90 \\
\hline A20 & 86 & 90 & 86 & 66 & 90 \\
\hline A21 & 78 & 79 & 80 & 76 & 90 \\
\hline A22 & 80 & 79 & 82 & 78 & 85 \\
\hline A23 & 79 & 80 & 82 & 72 & 90 \\
\hline A24 & 79 & 80 & 79 & 68 & 80 \\
\hline A25 & 79 & 78 & 80 & 70 & 90 \\
\hline A26 & 79 & 78 & 80 & 64 & 90 \\
\hline A27 & 79 & 80 & 80 & 66 & 90 \\
\hline A28 & 79 & 79 & 80 & 70 & 85 \\
\hline
\end{tabular}

3. Melakukan noramalisasi matrik keputusan $X$ dengan cara menghitung nilai rating kinerja ternormalisasi (Rij) dari alternatif ( $\mathrm{Ai})$ pada kriteria $(\mathrm{Cj})$, dengan persamaan:

$$
r_{i j}= \begin{cases}\frac{x_{i j}}{\operatorname{Max}_{i} X_{i j}} & \text { Jika } \mathrm{j} \text { adalah atribut keuntungan (benefit) } \\ \frac{\operatorname{Min}_{\mathrm{i}} \mathrm{x}_{\mathrm{ij}}}{\mathrm{X}_{\mathrm{ij}}} & \text { Jika } \mathrm{j} \text { adalah atribut biaya (cost) }\end{cases}
$$




\section{Jurnal Terapan Sains \& Teknologi}

Fakultas Sains dan Teknologi - Universitas Kanjuruhan Malang

4. Hasil akhir nilai preferensi (Vi) diperoleh dari penjumlahan dari perkalian elemen baris matrik ternormalisasi (R) dengan bobot preferensi (W) yang bersesuaian elemen kolom matrik $(\mathrm{W})$, Dengan persamaan untuk proses perangkingan sebagai berikut:

$$
V_{i}=\sum_{j=1}^{n} W_{j} r_{i j}
$$

$\mathrm{V}_{1}=(0,15 * 0,858695652)+(0,20 * 0,851064)+(0,20 * 0,831579)+(0,40 * 0,928571)+(0,05 * 1)$

$=(0,128804348+0,170212766+0,166315789+0,371428571+0,05)$

$=0,886761475$

$\mathrm{V}_{2}=(0,15 * 0,858695652)+(0,20 * 0,829787)+(0,20 * 0,831579)+(0,40 * 0,904762)+(0,05 * 888889)$

$=(0,128804348+0,165957447+0,166315789+0,361904762+0,044444444)$

$=0,86742679$

$\mathrm{V}_{3}=(0,15 * 0,858695652)+(0,20 * 0,829787)+(0,20 * 0,836842)+(0,40 * 0,833333)+(0,05 * 1)$

$=(0,128804348+0,165957447+0,167368421+0,333333333+0,05)$

$=0,845463549$

$\mathrm{V}_{4}=(0,15 * 0,891304348)+(0,20 * 0,851064)+(0,20 * 0,863158)+(0,40 * 0,904762)+(0,05 * 944444)$

$=(0,133695652+0,170212766+0,172631579+0,361904762+0,047222222)$

$=0,885666981$

$\mathrm{V}_{5}=(0,15 * 0,847826087)+(0,20 * 0,840426)+(0,20 * 0,836842)+(0,40 * 0,809524)+(0,05 * 1)$

$=(0,127173913+0,168085106+0,167368421+0,323809524+0,05)$

$=0,836436964$

$\mathrm{V}_{6}=(0,15 * 0,847826087)+(0,20 * 0,829787)+(0,20 * 0,836842)+(0,40 * 0,833333)+(0,05 * 944444)$

$=(0,127173913+0,165957447+0,167368421+0,333333333+0,047222222)$

$=0,841055336$

$\mathrm{V}_{7}=(0,15 * 0,847826087)+(0,20 * 0,840426)+(0,20 * 0,836842)+(0,40 * 0,785714)+(0,05 * 1)$

$=0,127173913+0,168085106+0,167368421+0,314285714+0,05)$

$=0,826913155$

$\mathrm{V}_{8}=(0,15 * 0,847826087)+(0,20 * 0,851064)+(0,20 * 0,847368)+(0,40 * 0,928571)+(0,05 * 944444)$

$=(0,127173913+0,170212766+0,169473684+0,371428571+0,047222222)$

$=0,885511157$

$\mathrm{V}_{9}=(0,15 * 0,967391304)+(0,20 * 0,957447)+(0,20 * 0,910526)+(0,40 * 0,97619)+(0,05 * 1)$

$=(0,145108696+0,191489362+0,182105263+0,39047619+0,05)$

$=0,959179511$

$\mathrm{V}_{10}=(0,15 * 0,891304348)+(0,20 * 0,897163)+(0,20 * 0,889474)+(0,40 * 0,904762)+(0,05 * 1)$

$=(0,133695652+0,179432624+0,177894737+0,361904762+0,05)$

$=0,902927775$

$\mathrm{V}_{11}=(0,15 * 0,913043478)+(0,20 * 0,921986)+(0,20 * 0,894737)+(0,40 * 0,785714)+(0,05 * 944444)$

$=(0,136956522+0,184397163+0,178947368+0,314285714+0,047222222)$

$=0,86180899$

$\mathrm{V}_{12}=(0,15 * 0,913043478)+(0,20 * 0,921986)+(0,20 * 0,894737)+(0,40 * 0,857143)+(0,05 * 1)$

$=(0,136956522+0,184397163+0,178947368+0,342857143+0,05)$

$=0,893158196$

$\mathrm{V}_{13}=(0,15 * 0,967391304)+(0,20 * 0,957447)+(0,20 * 1)+(0,40 * 0,952381)+(0,05 * 1)$

$=(0,145108696+0,191489362+0,2+0,380952381+0,05)$

$=0,967550438$

$\mathrm{V}_{14}=(0,15 * 0,956521739)+(0,20 * 1)+(0,20 * 1)+(0,40 * 0,97619)+(0,05 * 1)$

$=(0,143478261+0,2+0,2+0,39047619+0,05)$

$=0,983954451$

$\mathrm{V}_{15}=(0,15 * 0,97826087)+(0,20 * 0,93617)+(0,20 * 0,947368)+(0,40 * 0,952381)+(0,05 * 1)$

$=(0,14673913+0,187234043+0,189473684+0,380952381+0,05)$

$=0,954399238$

$\mathrm{V}_{16}=(0,15 * 1)+(0,20 * 0,957447)+(0,20 * 0,968421)+(0,40 * 1)+(0,05 * 1)$

$=(0,15+0,191489362+0,193684211+0,4+0,05)$

$=0,985173572$

$\mathrm{V}_{17}=(0,15 * 0,934782609)+(0,20 * 0,957447)+(0,20 * 0,915789)+(0,40 * 0,904762)+(0,05 * 1)$

$=(0,140217391+0,191489362+0,183157895+0,361904762+0,05)$

$=0,92676941$

$\mathrm{V}_{18}=(0,15 * 0,902173913)+(0,20 * 0,957447)+(0,20 * 0,9)+(0,40 * 0,833333)+(0,05 * 944444)$

$=(0,135326087+0,191489362+0,18+0,333333333+0,047222222)$ 
$=0,887371004$

$\mathrm{V}_{19}=(0,15 * 0,934782609)+(0,20 * 0,957447)+(0,20 * 0,905263)+(0,40 * 0,857143)+(0,05 * 1)$

$=(0,140217391+0,191489362+0,181052632+0,342857143+0,05)$

$=0,905616527$

$\mathrm{V}_{20}=(0,15 * 0,934782609)+(0,20 * 0,957447)+(0,20 * 0,905263)+(0,40 * 0,785714)+(0,05 * 1)$

$=(0,140217391+0,191489362+0,181052632+0,314285714+0,05)$

$=0,877045099$

$\mathrm{V}_{21}=(0,15 * 0,847826087)+(0,20 * 0,840426)+(0,20 * 0,842105)+(0,40 * 0,904762)+(0,05 * 1)$

$=(0,127173913+0,168085106+0,168421053+0,361904762+0,05)$

$=0,875584834$

$\mathrm{V}_{22}=(0,15 * 0,869565217)+(0,20 * 0,840426)+(0,20 * 0,857895)+(0,40 * 0,928571)+(0,05 * 944444)$

$=(0,130434783+0,168085106+0,171578947+0,371428571+0,047222222)$

$=0,88874963$

$\mathrm{V}_{23}=(0,15 * 0,858695652)+(0,20 * 0,851064)+(0,20 * 0,857895)+(0,40 * 0,857143)+(0,05 * 1)$

$=(0,128804348+0,170212766+0,171578947+0,342857143+0,05)$

$=0,863453204$

$\mathrm{V}_{24}=(0,15 * 0,858695652)+(0,20 * 0,851064)+(0,20 * 0,831579)+(0,40 * 0,809524)+(0,05 * 888889)$

$=(0,128804348+0,170212766+0,166315789+0,323809524+0,044444444)$

$=0,833586872$

$\mathrm{V}_{25}=(0,15 * 0,858695652)+(0,20 * 0,829787)+(0,20 * 0,836842)+(0,40 * 0,833333)+(0,05 * 1)$

$=(0,128804348+0,165957447+0,167368421+0,333333333+0,05)$

$=0,845463549$

$\mathrm{V}_{26}=(0,15 * 0,858695652)+(0,20 * 0,829787)+(0,20 * 0,842105)+(0,40 * 0,761905)+(0,05 * 1)$

$=(0,128804348+0,165957447+0,168421053+0,304761905+0,05)$

$=0,817944752$

$\mathrm{V}_{27}=(0,15 * 0,858695652)+(0,20 * 0,851064)+(0,20 * 0,836842)+(0,40 * 0,785714)+(0,05 * 1)$

$=(0,128804348+0,170212766+0,167368421+0,314285714+0,05)$

$=0,830671249$

$\mathrm{V}_{28}=(0,15 * 0,858695652)+(0,20 * 0,840426)+(0,20 * 0,842105)+(0,40 * 0,833333)+(0,05 * 944444)$

$=(0,128804348+0,168085106+0,168421053+0,333333333+0,047222222)$

$=0,845866062$

Hasil dari perhitungan di atas adalah:

Tabel 6. Hasil Preferensi

\begin{tabular}{ccccclc}
\hline Alternatif & $\mathbf{C 1}$ & $\mathbf{C 2}$ & $\mathbf{C 3}$ & $\mathbf{C 4}$ & \multicolumn{1}{c}{ C5 } & HASIL \\
\hline V1 & 0,1288043 & 0,1702128 & 0,1663158 & 0,3714286 & 0,05 & 0,886761475 \\
\hline V2 & 0,1288043 & 0,1659574 & 0,1663158 & 0,3619048 & 0,0444444 & 0,86742679 \\
\hline V3 & 0,1288043 & 0,1659574 & 0,1673684 & 0,3333333 & 0,05 & 0,845463549 \\
\hline V4 & 0,1336957 & 0,1702128 & 0,1726316 & 0,3619048 & 0,0472222 & 0,885666981 \\
\hline V5 & 0,1271739 & 0,1680851 & 0,1673684 & 0,3238095 & 0,05 & 0,836436964 \\
\hline V6 & 0,1271739 & 0,1659574 & 0,1673684 & 0,3333333 & 0,0472222 & 0,841055336 \\
\hline V7 & 0,1271739 & 0,1680851 & 0,1673684 & 0,3142857 & 0,05 & 0,826913155 \\
\hline V8 & 0,1271739 & 0,1702128 & 0,1694737 & 0,3714286 & 0,0472222 & 0,885511157 \\
\hline V9 & 0,1451087 & 0,1914894 & 0,1821053 & 0,3904762 & 0,05 & 0,959179511 \\
\hline V10 & 0,1336957 & 0,1794326 & 0,1778947 & 0,3619048 & 0,05 & 0,902927775 \\
\hline V11 & 0,1369565 & 0,1843972 & 0,1789474 & 0,3142857 & 0,0472222 & 0,86180899 \\
\hline V12 & 0,1369565 & 0,1843972 & 0,1789474 & 0,3428571 & 0,05 & 0,893158196 \\
\hline V13 & 0,1451087 & 0,1914894 & 0,2 & 0,3809524 & 0,05 & 0,967550438 \\
\hline V14 & 0,1434783 & 0,2 & 0,2 & 0,3904762 & 0,05 & 0,983954451 \\
\hline V15 & 0,1467391 & 0,187234 & 0,1894737 & 0,3809524 & 0,05 & 0,954399238 \\
\hline V16 & $\mathbf{0 , 1 5}$ & $\mathbf{0 , 1 9 1 4 8 9 4}$ & $\mathbf{0 , 1 9 3 6 8 4 2}$ & $\mathbf{0 , 4}$ & $\mathbf{0 , 0 5}$ & $\mathbf{0 , 9 8 5 1 7 3 5 7 2}$ \\
\hline V17 & 0,1402174 & 0,1914894 & 0,1831579 & 0,3619048 & 0,05 & 0,92676941 \\
\hline V18 & 0,1353261 & 0,1914894 & 0,18 & 0,3333333 & 0,0472222 & 0,887371004 \\
\hline V19 & 0,1402174 & 0,1914894 & 0,1810526 & 0,3428571 & 0,05 & 0,905616527 \\
\hline V20 & 0,1402174 & 0,1914894 & 0,1810526 & 0,3142857 & 0,05 & 0,877045099 \\
\hline V21 & 0,1271739 & 0,1680851 & 0,1684211 & 0,3619048 & 0,05 & 0,875584834 \\
\hline V22 & 0,1304348 & 0,1680851 & 0,1715789 & 0,3714286 & 0,0472222 & 0,88874963 \\
\hline V23 & 0,1288043 & 0,1702128 & 0,1715789 & 0,3428571 & 0,05 & 0,863453204 \\
\hline
\end{tabular}


Jurnal Terapan Sains \& Teknologi

Fakultas Sains dan Teknologi - Universitas Kanjuruhan Malang

Vol. 2, No. 2, 2020

\begin{tabular}{rrrrrll}
\hline V24 & 0,1288043 & 0,1702128 & 0,1663158 & 0,3238095 & 0,0444444 & 0,833586872 \\
\hline V25 & 0,1288043 & 0,1659574 & 0,1673684 & 0,3333333 & 0,05 & 0,845463549 \\
\hline V26 & 0,1288043 & 0,1659574 & 0,1684211 & 0,3047619 & 0,05 & 0,817944752 \\
\hline V27 & 0,1288043 & 0,1702128 & 0,1673684 & 0,3142857 & 0,05 & 0,830671249 \\
\hline V28 & 0,1288043 & 0,1680851 & 0,1684211 & 0,3333333 & 0,0472222 & 0,845866062 \\
\hline
\end{tabular}

Dari hasil perhitungan Preferensi di atas dapat ditentukan siswa yang akan menajadi calon peserta Olimpiade Sains Nasional (OSN) tingkat kabupaten dengan nilai tertinggi 0,98517357 atas nama Ratri Divandari dengan kode Alternativ V16.

Berikut adalah Interface halaman laporan yang ada pada sistem berdasarkan hasil perhitungan data di atas.

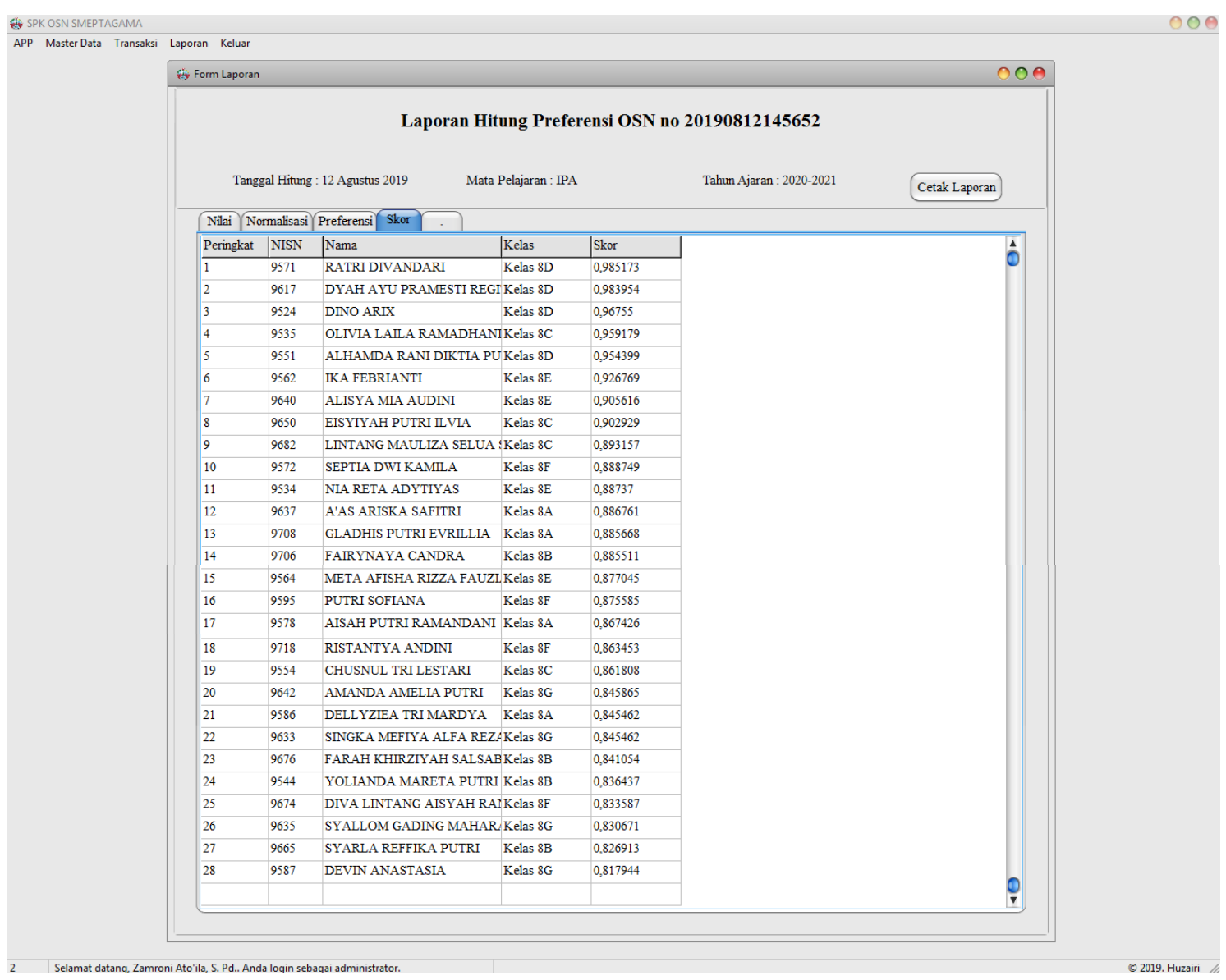

Gambar 5. Halaman Perhitungan Preferensi Calon Peserta OSN

\section{PENUTUP}

\section{Kesimpulan}

Kesimpulan dari hasil penelitian yang telah dilakukan oleh peneliti adalah sebagai berikut:

a) Telah berhasil membangun sistem pendukung keputusan dengan menerapkan metode SAW (Simple Additive Weighting) yang dapat menyeleksi calon peserta OSN (Olimpiade Sains Nasional) di SMPN 1 Ampelgading dengan proses sistem login, master data siswa, master data kelas, master data kriteria, master data pengguna serta data penyimpanan berupa database $M y S Q L$.

b) Sistem ini mampu melakukan perhitungan dengan penerapan metode SAW (Simple Additive Weighting) yang sudah sesuai dengan perhitungan manual dan menghasilkan perhitungan yang sama dengan sistem. 


\section{Jurnal Terapan Sains \& Teknologi}

Fakultas Sains dan Teknologi - Universitas Kanjuruhan Malang

Vol. 2, No. 2, 2020

c) Sistem ini mampu memberikan rekomendasi terbaik bagi calon peserta yang layak mewakili sekolah dalam lomba Olimpiade Sains Nasional (OSN) tingkat kabupaten dan mampu mempermudah panitia dalam pemilihan calon peserta Olimpiade Sains Nasional (OSN) tingkat kabupaten sesuai dengan kompetensi siswa terbaik.

\section{Saran Pengembangan}

Adapun saran yang ditujukan untuk memberikan masukan yang lebih baik yaitu:

a) Sistem dapat dikembangkan dengan menggunakna metode AHP, WP, TOPSIS, atau kombinasi dengan beberapa metode untuk mendapatkan hasil perbandingan yang lebih akurat.

b) Sistem dapat dikembangkan berbasis web, jika pengelolaan dibutuhkan banyak user, ataupun diinformasikan ke banyak orang.

c) Metode SAW (Simple Additive Weighting) dapat diterapkan pada permasalahan keputusan selain dari pemilihan calon peserta Olimpiade Sains Nasional (OSN).

\section{DAFTAR RUJUKAN}

Darmastuti. 2013. Implementasi Metode Simple Additive Weighting (SAW) dalam Sistem Informasi Lowongan Kerja Berbasis Web untuk Rekomendasi Pencari Kerja Terbaik

Harold Situmorang. 2015. Sistem Pendukung Keputusan Pemilihan Calon Peserta Olimpiade Sains Tingkat Kabupaten Langkat pada Madrasah Aliyah Negeri (MAN) 2 Tanjung Pura dengan Menggunakan Metode Simple Additive Weighting (SAW)

Johni S Pasaribu. 2017. Implementasi Sistem Pendukung Keputusan Metode Simple Additive Weighting Pemilihan Siswa Olimpiade Sains Tingkat Kota di SMAN 11 Bandung

Nofriansyah, Dicky. 2014. Konsep Data Mining vs Sistem Pendukung Keputusan. Yogyakarta: Deepublish

Permadi Setiawan, Sulistiowati dan Julianto Lemantara. 2015 Rancang Bangun Aplikasi Pengolahan Data Evaluasi Proses Belajar Mengajar Berbasis Web Pada Stikes Yayasan Rs. Dr. Soetomo Surabaya

Utomo. 2016. Penerapan Metode SAW (Simple Additive Weighting) pada Sistem Pendukung Keputusan Untuk Pemberian Beasiswa pada SMA Negeri 1 Cepu Jawa Tengah

Widyaningsih dan Giovanni. 2016. Penentuan Peserta Lomba Kompetensi Siswa Menggunakan Simple Additive Weighting (SAW) Studi Kasus SMK Negeri 2 Palangkaraya 